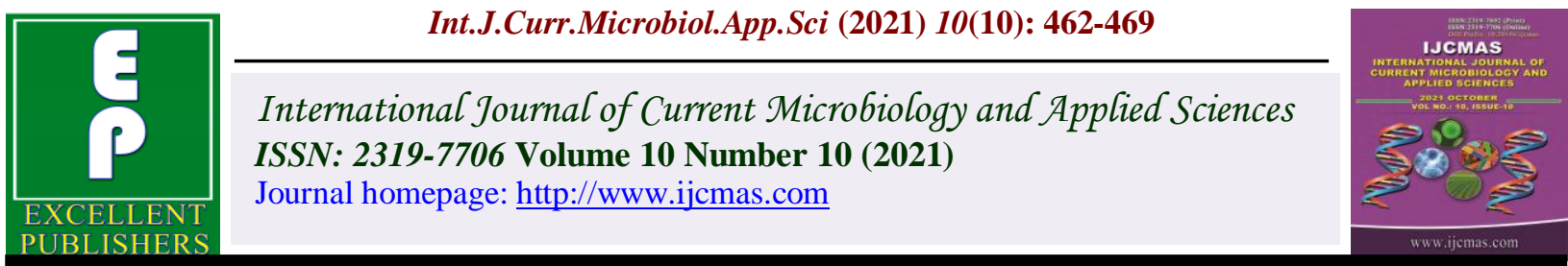

\title{
Development of A Mobile Phone Application and its Efficacy Assessment Concerning the Changes in Anthropometric Measurements, and Dietary and Nutrient Adequacy of Hundred Obese Females of Udaipur City Rajasthan
}

\author{
Sehar Siddiqui* \\ Department of Food Science and Nutrition, College of Community and Applied Sciences, \\ Udaipur, Rajasthan, India \\ *Corresponding author
}

Keywords

Mhealth,

Anthropometric

assessment,

lifestyle changes

Article Info

Accepted:

18 September 2021

Available Online:

10 October 2021
The present study was conducted to administer overweight and obesity by suggesting various nutritional and lifestyle intervention programs through planning, designing, and formulating mobile-based Mhealth technique. The study intended to assess the efficacy of the designed health mobile application in bringing out the various dietary and nutritional modifications in the lives of those who are at the risk of overweight and its related major health issues. To accomplish the above objective hundred obese women residing in Udaipur city were selected and studied. Mobile application was then developed by gathering authentic nutritional pieces of information from different sources, books, internet, journals. Application was then installed in the smart phones of the respondents' testing of anthropometric measurements like height, weight, BMI, WHR along with dietary and nutrient adequacy was assessed on 0 day the mean height was $164.74 \pm 4.89 \mathrm{~cm}$, the mean weight was $72.9 \pm 14.92 \mathrm{~kg}$, and the mean BMI was $28.23 \pm 2.36 \mathrm{~kg} / \mathrm{m}^{2}$, and the mean WHR was $0.86 \pm 0.07 \mathrm{~cm}$. Again, post assessment of Anthropometric measurement as well as dietary and nutrient adequacy was recorded on, 90, 120, 150, 180 and changes occurred was observed. It was observed that the mean height remained constant. Whereas there was a change in mean weight, bmi, where, it was evident from the data of dietary and nutrient assessment. It was considerably deficient in green leafy vegetables, other vegetables, and fruits. Cereals, pulses, milk and milk products, sugar, and fat, on the other hand, were substantially higher in consumption as compared to balanced diets. Also, the female respondents' diet was substantially deficient in the following nutrients: vitamin A, vitamin C, and iron. On the other hand, the diet was high in energy, protein, carbohydrates, fats, calcium. Significant improvements were observed in the post-assessment, with reduced intake of sugar, fats, and oil, and increased intake of roots, green leafy vegetables, other vegetables, fruits, and pulses. 


\section{Introduction}

Obesity is a condition with excessive fat accumulation in the body to the extent that the health and wellbeing of the individual is adversely affected. It is an abnormal growth of adipose tissue due to enlargement of fat cell size (hypertrophic obesity) or an increase in fat cell number (hyperplastic obesity) or a combination of both (Park \& Park 2002). It is a serious ailment that threatens global wellbeing (WHO Technical Report Series 2015). It has been described as the 'New World Syndrome' which creates an enormous socio-economic and public burden. The incidence of obesity is escalating at an alarming rate. Over the past decade, levels have increased at the global level on an average between 10-40\% globally over 1 billion people are overweight, including 805 million women, and among them over 300 million people are obese (WHO global report 2015). Overweight and obesity are emerging health problems in India. According to National health problems in India -3 (NFHS3 ), thirteen percent of women (15-49) and nine percent of adults were overweight or obese in 2005-2006 and its prevalence was higher in urban areas as compared to rural areas. The prevalence is more profound in the women of age between 40-49 years (23.7\%), residing in cities $(23.5 \%)$, having high qualification (23.8\%), belonging to the Sikh community (31.6\%), and households in the highest wealth quintile $(30.5 \%)$. The highest percentage of obese women is found in Punjab (29.9\%).

The NFHS-4 survey 2015-2016 highlights that the urban population is more prone to obesity as compared to their rural counterparts. In Andhra Pradesh, 44.4 percent of urban men suffered from obesity, while the percentage in rural parts was 28 percent. Similarly, 45.6 percent of the urban women in the state were obese against the 27.6 percent of women in rural Andhra Pradesh.

\section{Materials and Methods}

Purposive sampling technique was used for sample selection. One fifty to one sixty women ranging between 20-40 years of age had been screened for baseline survey and inclusion in the study. Their weight, height was also recorded and BMI was calculated. Based on the BMI range i.e.(25->30) hundred women of 20-40 years had been selected for the study. A structured Performa was developed keeping in sight the information to be collected from the study sample regarding their pertaining obesity and lifestyle pattern and dietary habits and nutrition intake. The particulars of the age, sex, family history, past medical history, personal habits (alcohol, smoking, drugs, tobacco), food habits, height, weight, body mass index, were collected for pre-investigation of the study. Exhaustive literary study from books, journals, the internet was carried on obesity-related information to design the mobile application. Data were then converted into Power Point presentations and then converted into the mobile application which was then tested for post-intervention on the selected subjects in the interval period of 30 days starting from 0 day, 90 days, 120 days, 150 days, 180-day, Post assessment and efficacy concerning selected markers was recorded on 180 days.

\section{Results and Discussion}

All respondent selected were laying in the age group of 20 to 40 years of age, and free from medical complications like hypertension, PCOS, cancer, diabetes, depression, lactation, and pregnancy. Out of 100 respondents, majority of them were married $(55 \%)$, rest $(40 \%)$ were unmarried and only a few (2\%)and (3\%)were Divorce and widow. Majority of the respondents i.e (40\%) were postgraduate $(35 \%)$ were graduates and the rest $(25 \%)$ completed higher education only. It is evident from the data that (30\%) were from 
upper class $(20 \%)$ and $(20 \%)$ were from the upper-middle class and middle class simultaneously whereas $(15 \%)$ and $(15 \%)$ were from lower-middle and lower class respectively also no one was from B.P.L class. Changes in anthropometry were also recorded on 0 day.

\section{Anthropometric measurements of female respondents assessed on 0 day}

The height of an individual may vary depending upon his/her genes various environmental factors, consumption of food and the right amount of nutrients. The mean height of the respondents remained constant and it was observed in pre-investigation the mean height of the respondents were 161.21士 $4.65 \mathrm{~cm}$. Weigh tone of the important anthropometric measures to analyze the major body constituents like fat, fat-free mass, extracellular mass, and intracellular fluid.etc. Overall weight of the respondents on 0 day was $72.91 \pm 4.92 \mathrm{~kg}$. Body mass index is a direct co-relation of body weight to its height it is commonly classified according to WHO IOTF standards. The mean BMI of the respondents on 0 day was $28.23 \pm 2.36 \mathrm{~kg}$ $/ \mathrm{m}^{2}$.The Waist-to-hip Ratio (WHR) identifies the proportion of fat stored on one's body around the waist and hip. The mean WHR on0 day it was $0.86 \pm 0.07 \mathrm{~cm}$.

Cereals are a major part of the Indian diet. They are the major source of energy and several other nutrients. On 0 day the mean Mean \pm SD is 194.66 \pm 44.38 , and the Percentage was $71.85 \%$. If we talk about the pulse consumption the suggestion for pulse consumption according to RDI is $60 \mathrm{~g} / \mathrm{d}$. The mean intake of pulse consumed by the respondents on 0 day was $45.98 \pm 20.88$. was $75 \%$ of R.D.A. Milk is an excellent source of protein, providing calcium and riboflavin. It was noted that the mean intake of milk and milk products on 0 day was $238.80 \pm 12.43$ which was $79.6 \%$ of the diet. Observation of data reveals the mean intake of roots and tubers on 0 day was $113.52 \pm 83.62$ which was $56.76 \%$ of the diet. Green leafy vegetables are loaded with iron, calcium, vitamin $C, \beta$ carotene, folic acid, riboflavin. Observation of data reveals the mean intake of green leafy vegetable on 0 day was $35.89 \pm 36.14$ which was $15.84 \%$. Other vegetables are those vegetables which are neither green leafy vegetable nor roots or tubers the mean intake of other vegetables on 0 day was $27.45 \pm 21.70$ which was $27 \%$ of diet. Fruits contain fiber and pectin. On 0 day the mean intake of fruits was $30.08 \pm 25.04$ which was $30.08 \%$ of diet. As Sugar is an important ingredient of day-today life is consumed by almost everyone in some of the other forms. On 0 day it was visible that the mean intake of sugar was $17.10 \pm 4.4$ which was $85.5 \%$ of diet. Fats are an excellent source of essential fatty acids. But excess fat intake often causes obesity on 0 day the mean intake was $25.66 \pm 5.04$ which was $128.3 \%$ of diet. A non-vegetarian diet which primarily includes meat, fish, eggs, and dairy food is a good source of protein. Vitamin B 12 , and iron. On 0 day it was $1.6 \pm 6.48$ which was $2.6 \%$ of diet.

Post Assessment of anthropometric measurements and dietary adequacy of 100 female respondents on 90,120,150,180, day to check the efficacy of the developed mobile application.

The mean height of the respondents remained constant and it was observed as earlier as in pre-investigation i.e. $161.21 \pm 4.65 \mathrm{~cm}$. Talking about the weight. A visible difference in weight was clearly observed on 90, 120, 150and 180-dayie on 90 day it was $71.17 \pm 4.91$ $\mathrm{kg}$ on 120 it was $71.15 \pm 4.90 \mathrm{~kg}$ and on 150 and 180 day it was $71.13 \pm 4.88 \mathrm{~kg}$ and $70.88 \pm 4.91 \mathrm{~kg}$ simultaneously. Difference in BMI was also clearly observed on 90 day it was $27.13 \pm 1.74 \mathrm{~kg} / \mathrm{m}^{2}$ on 120 it was 27.11 $\pm 1.73 \mathrm{~kg} / \mathrm{m}^{2}$ and on 150 and 180 day it was $27.9 \pm 1.72 \mathrm{~kg} / \mathrm{m}^{2}$ and $27.18 \pm 1.74 \mathrm{~kg} / \mathrm{m}^{2}$. 
Simultaneously a marked difference in the WHR was also clearly evident. On 90 day it was $0.84 \pm 0.06 \mathrm{~cm}$ on 120 day it was 0.82 $\pm 0.05 \mathrm{~cm}$ and on 150 and 180 day it was $0.80 \pm 0.03 \mathrm{~cm}$ and $0.80 \pm 0.03 \mathrm{~cm}$ simultaneously. The study was in line with the study of Binu and Rajendra, (2014) where they studied the prevalence of overweight and obesity and its influencing factors among rural geriatric population in Kerala stated the findings as total number of 89 subjects who were aged 60 years and above were screened for their height, weight and thus body mass index were calculated. Out of 89 subjects, 55 $(62 \%)$ were women and $34(38 \%)$ were men. Mean age of the population was 66 years. Average age of males was found to be 67 years and that of females is 65 years. The study reveals prevalence of geriatric overweight / obesity to be 54\%.It was observed that $47 \%$ of males and $58 \%$ of females were overweight and obese.

Post assessment and Changes in dietary adequacy of the female respondents with respect to developed mobile phone application on $90,120,150,180$ day. Diet is a major determinant of the health and nutritional status of people. The dietary habits may vary according to socio-economic factors, regional customs, and traditions. One such technique of 24 recall method for three days was used to find out their dietary adequacy which was then computed as expressed as a percentage of balance diet (NIN 2020). Dietary adequacy of cereals, pulses, milk and milk products, roots and tubers, green leafy vegetables, fruits, fats and oils, meat and meat products, sugar was assessed on 0, 90, 120, 150, 180 day.

Post observation of dietary adequacy of hundred female respondents it was very well observed that the dietary adequacy of the female respondents saw a major change on 90, 120, 150, 180 day. This clearly signifies that the application thus developed created a positive impact on their dietary habits.

\section{Cereals}

Cereals are a major part of the Indian diet. They are the major source of energy and several other nutrients. These are the cheapest accessible resource of nutrients, predominantly in developing countries. $90^{\text {th }}$ day which was $169.83 \pm 17$.1i.e $69.2 \%$ of the diet, Similarly the mean intake of cereals on $120^{\text {th }}$ day was $166.86 \pm 32.89$ which was $61.8 \%$ of the diet, the mean intake reported on $150^{\text {th }}$ day reported was $173.86 \pm 20.38$ which was $64.39 \%$ of the diet and on $180^{\text {th }}$ day the mean intake was $175.5 \pm 21.9$ Which was $65 \%$ of the diet.

\section{Pulses}

On $90^{\text {th }}$ day which was $41.81 \pm 9.51$ i.e $69.68 \%$ of the diet, Similarly the mean intake of cereals on 120 was $40.20 \pm 10.32$ which was $67 \%$ of the diet, the mean intake reported on $150^{\text {th }}$ day reported was $40.15 \pm 10.92$ which was $66.91 \%$ of the diet and on $180^{\text {th }}$ day the mean intake was $30.48 \pm 9.38$ Which was $50.8 \%$ of the diet

\section{Milk and milk products}

On $90^{\text {th }}$ day which was $232.08 \pm 24.35$ i.e $77.36 \%$ of the diet, Similarly the mean intake of milk products on $120^{\text {th }}$ Daywas $219.51 \pm 43.86$ which was $67 \%$ of the diet, the mean intake reported on $150^{\text {th }}$ day was $217.87 \pm 27.11$ which was $72.62 \%$ of the diet and on $180^{\text {th }}$ day the mean intake was $217.87 \pm 27.11$ which was $72.62 \%$ of the diet.

\section{Roots and tubers}

On $90^{\text {th }}$ day was $30.20 \pm 25.98$ i.e., $11.80 \%$ of the diet, Similarly the mean intake of roots on $120^{\text {th }}$ Day was $30.20 \pm 25.98$ which was $15 \%$ of the diet, the mean intake reported on $150^{\text {th }}$ day was $26.16 \pm 18.84$ which was $13.08 \%$ of the diet and on $180^{\text {th }}$ day the mean intake was $28.51 \pm 23.29$.which was $14.25 \%$ of the diet. 


\section{Green leafy vegetables (GLVs)}

$90^{\text {th }}$ day green leafy vegetable was $65.45 \pm 66.52$ i.e., $65.45 \%$ of the diet, Similarly the mean intake of roots on $120^{\text {th }}$ Daywas $66.29 \pm 63.31$ which was $66.29 \%$ of the diet, the mean intake reported on $150^{\text {th }}$ day was $65.79 \pm 66.71$ which was $65.79 \%$ of the diet and on $180^{\text {th }}$ day the mean intake was $68.48 \pm 71.03$. Which was $68.48 \%$ of the diet.

\section{Other Vegetable}

On $90^{\text {th }}$ day other vegetable was $127.96 \pm 92.68$ i.e.63.98\% of the diet, Similarly the mean intake of other vegetables on $120^{\text {th }}$ Daywas $128.15 \pm 77.10$ which was $64.07 \%$ of the diet, the mean intake reported on $150^{\text {th }}$ day was $124.63 \pm 92.12$ which was $62.31 \%$ of the diet and on $180^{\text {th }}$ day the mean intake was $126.96 \pm 94.56$. which was $63.48 \%$ of the diet.

\section{Fruits}

Fruits are normally a high-quality source of vitamin C. Also, they offer $\beta$ carotene energy and iron. Fruits also contain fiber and pectin, which helps in relieving constipation. On $90^{\text {th }}$ day the mean fruit intake was $69.33 \pm 35.82$ i.e.63.98\% of the diet, Similarly the mean intake of fruits on $120^{\text {th }}$ Daywas $128.15 \pm 77.10$ which was $64.07 \%$ of the diet, the mean intake reported on $150^{\text {th }}$ day was $124.63 \pm 92.12$ which was $62.31 \%$ of the diet and on $180^{\text {th }}$ day the mean intake was $126.96 \pm 94.56$. which was $63.48 \%$ of the diet.

\section{Sugar}

As Sugar is an important ingredient of day-today life is consumed by almost everyone in some of the other forms be it beverages, or chocolates, sugar-based confectionaries.

On $90^{\text {th }}$ day was $7.06 \pm 2.18$ i.e., $35.3 \%$ of the diet, Similarly the mean intake of sugar on $120^{\text {th }}$ Day was $6.9 \pm 2.06$ which was $34.5 \%$ of the diet, the mean intake reported on $150^{\text {th }}$ day was $7.8 \pm 2.9$ which was $39 \%$ of the diet and on $180^{\text {th }}$ day the mean intake was $7.9 \pm 2.9$, which was $39.5 \%$ of the diet.

Table.1 Anthropometric measurements of the 100 female respondents on 0 day

\begin{tabular}{|c|c|}
\hline S. No. & 0 Day \\
\hline Height $(\mathbf{c m})$ & $161.21 \pm 4.65 \mathrm{~cm}$ \\
\hline Weight $(\mathbf{k g})$ & $72.91 \pm 4.92 \mathrm{~kg}$ \\
\hline BMI $\left(\mathbf{k g} / \mathbf{m}^{2}\right)$ & $28.23 \pm 2.36 \mathrm{~kg} / \mathrm{m}^{2}$ \\
\hline WHR(cm) & $0.86 \pm 0.07 \mathrm{~cm}$ \\
\hline
\end{tabular}

$(\mathrm{N}=100)$

Table.2 Mean anthropometric assessment of female respondents on 90, 120, 150, 180 day

$(\mathrm{N}=100)$

\begin{tabular}{|c|c|c|c|c|}
\hline S. No & $\mathbf{9 0}$ & $\mathbf{1 2 0}$ & $\mathbf{1 5 0}$ & $\mathbf{1 8 0}$ \\
\hline Height & $161.21 \pm 4.65 \mathrm{~cm}$ & $161.21 \pm 4.65 \mathrm{~cm}$ & $\begin{array}{c}161.21 \pm 4.65 \\
\mathrm{~cm}\end{array}$ & $\begin{array}{c}161.21 \pm 4.65 \\
\mathrm{~cm}\end{array}$ \\
\hline Weight & $71.17 \pm 4.91 \mathrm{~kg}$ & $71.15 \pm 4.90 \mathrm{~kg}$ & $\begin{array}{l}71.13 \pm 4.88 \mathrm{~kg} \\
70.88 \pm 4.91 \mathrm{~kg}\end{array}$ \\
\hline BMI & \begin{tabular}{c}
$27.13 \pm 1.74 \mathrm{~kg}$ \\
\hline $\mathrm{m}^{2}$
\end{tabular} & $\begin{array}{c}27.11 \pm 1.73 \mathrm{~kg} \\
/ \mathrm{m}^{2}\end{array}$ & $\begin{array}{c}27.9 \pm 1.72 \mathrm{~kg} \\
/ \mathrm{m}^{2}\end{array}$ & $\begin{array}{c}27.18 \pm 1.74 \mathrm{~kg} \\
/ \mathrm{m}^{2}\end{array}$ \\
\hline WHR & $0.84 \pm 0.06 \mathrm{~cm}$ & $0.82 \pm 0.05 \mathrm{~cm}$ & $0.80 \pm 0.03 \mathrm{~cm}$ & $0.82 \pm 0.06 \mathrm{~cm}$ \\
\hline
\end{tabular}

Values arein Mean \pm SD 
Table.3 Mean dietary adequacy assessment of female respondents on 90, 120, 150, 180 day

\begin{tabular}{|c|c|c|c|c|c|c|}
\hline S no. & $\begin{array}{c}\text { Food } \\
\text { Product }\end{array}$ & $\begin{array}{c}\text { RDI } \\
\text { gm }\end{array}$ & 90 day & 120 day & 150 day & 180 day \\
\hline \multirow[t]{3}{*}{1} & Cereal & \multirow[t]{3}{*}{$270 \mathrm{gm}$} & & & & \\
\hline & Mean \pm SD & & $169.83 \pm 17.1$ & $166.86 \pm 32.89$ & $173.86 \pm 20.38$ & $175.5 \pm 21.9$ \\
\hline & Percentage & & $69.2 \%$ & $61.8 \%$ & $64.39 \%$ & $65 \%$ \\
\hline \multirow[t]{3}{*}{2} & Pulses & \multirow{3}{*}{$60 \mathrm{gm}$} & & & & \\
\hline & Mean \pm SD & & $41.81 \pm 9.51$ & $40.20 \pm 10.32$ & $40.15 \pm 10.92$ & $30.48 \pm 9.38$ \\
\hline & Percentage & & $69.68 \%$ & $67 \%$ & $66.91 \%$ & $50.8 \%$ \\
\hline \multirow[t]{3}{*}{3} & Milk \&Milk & \multirow{3}{*}{$300 \mathrm{ml}$} & & & & \\
\hline & Mean士 SD & & $232.08 \pm 24.35$ & $219.51 \pm 43.86$ & $217.87 \pm 27.11$ & $217.87 \pm 27.11$ \\
\hline & Percentage & & $77.36 \%$ & $73 \%$ & $72.62 \%$ & $72.62 \%$ \\
\hline \multirow[t]{3}{*}{4} & $\begin{array}{c}\text { Roots \& } \\
\text { Tuber }\end{array}$ & \multirow[t]{3}{*}{$200 \mathrm{gm}$} & & & & \\
\hline & Mean \pm SD & & $23.61 \pm 18.07$ & $30.20 \pm 25.98$ & $26.16 \pm 18.84$ & $28.51 \pm 23.29$ \\
\hline & Percentage & & $11.80 \%$ & $15 \%$ & $13.08 \%$ & $14.25 \%$ \\
\hline \multirow[t]{3}{*}{5} & $\begin{array}{l}\text { Green leafy } \\
\text { Vegetables }\end{array}$ & \multirow[t]{3}{*}{$100 \mathrm{gm}$} & & & & \\
\hline & Mean \pm SD & & $65.45 \pm 66.52$ & $66.29 \pm 63.31$ & $65.79 \pm 66.71$ & $68.48 \pm 71.03$ \\
\hline & percentage & & $65.45 \%$ & $66.29 \%$ & $65.79 \%$ & $68.48 \%$ \\
\hline \multirow[t]{3}{*}{6} & $\begin{array}{c}\text { Other } \\
\text { Vegetable }\end{array}$ & \multirow[t]{3}{*}{$200 \mathrm{gm}$} & & & & \\
\hline & Mean \pm SD & & $127.96 \pm 92.68$ & $128.15 \pm 77.10$ & $124.63 \pm 92.12$ & $126.96 \pm 94.56$ \\
\hline & Percentage & & $63.98 \%$ & $64.07 \%$ & $62.31 \%$ & $63.48 \%$ \\
\hline \multirow{3}{*}{7} & Fruits & \multirow{3}{*}{$100 \mathrm{gm}$} & & & & \\
\hline & Mean \pm SD & & $69.33 \pm 35.82$ & $74.66 \pm 37.86$ & $68.41 \pm 35.12$ & $69.41 \pm 35.41$ \\
\hline & Percentage & & $69.33 \%$ & $74 \%$ & $68.41 \%$ & $69.41 \%$ \\
\hline \multirow[t]{3}{*}{8} & Sugar & \multirow{3}{*}{$20 \mathrm{gm}$} & & & & \\
\hline & Mean \pm SD & & $7.06 \pm 2.18$ & $6.9 \pm 2.06$ & $7.8 \pm 2.9$ & $7.9 \pm 2.9$ \\
\hline & Percentage & & $35.3 \%$ & $34.5 \%$ & $39 \%$ & $39.5 \%$ \\
\hline \multirow[t]{3}{*}{9} & Fats \&Oils & \multirow{3}{*}{$20 \mathrm{gm}$} & & & & \\
\hline & Mean \pm SD & & $4.40 \pm 1.04$ & $4.4 \pm 1.04$ & $4.8 \pm 1.43$ & $5.0 \pm 1.4$ \\
\hline & Percentage & & $22 \%$ & $22 \%$ & $24 \%$ & $25 \%$ \\
\hline \multirow[t]{3}{*}{10} & $\begin{array}{c}\text { Meat } \\
\text { products }\end{array}$ & \multirow[t]{3}{*}{$60 \mathrm{gm}$} & & & & \\
\hline & Mean \pm SD & & $6.5 \pm 16.39$ & $8.0 \pm 17.32$ & $7.5 \pm 12.83$ & $9.8 \pm 16.08$ \\
\hline & Percentage & & $10.8 \%$ & $13.3 \%$ & $12.5 \%$ & $16.33 \%$ \\
\hline
\end{tabular}

Values are in Mean \pm SD

RDA - Recommended Dietary Allowances, ICMR-2020 


\section{Fats and oils}

Visible fats in the form of hydrogenated fat, oil, ghee is an essential part of a regular Indian diet. Fats are an excellent source of essential fatty acids. Intake of fats and oils on $90^{\text {th }}$ day was $4.40 \pm 1.04$ i.e. $22 \%$ of the diet, Similarly the mean intake of fats on $120^{\text {th }}$ Day was $4.4 \pm 1.04$ which was $22 \%$ of the diet, the mean intake reported on $150^{\text {th }}$ day was $4.8 \pm 1.43$ which was $24 \%$ of the diet and on $180^{\text {th }}$ day the mean intake was, $5.0 \pm 1.4$ which was $25 \%$ of the diet.

\section{Meat products}

A non-vegetarian diet which primarily includes meat, fish, eggs, and dairy food is a good source of protein. Vitamin B 12 and iron. The mean intake of meat on $90^{\text {th }}$ day was $6.5 \pm 16.39$ i.e., $10.8 \%$ of the diet, Similarly the mean intake of meat on $120^{\text {th }}$ Day was $8.0 \pm 17.32$ which was $13.3 \%$ of the diet, the mean intake reported on $150^{\text {th }}$ day was $7.5 \pm 12.83$ which was $12.5 \%$ of the diet and on $180^{\text {th }}$ day the mean intake was, $9.8 \pm 16.08$ which was $16.33 \%$ of the diet.

The developed application brought a significant change in the lives of the female respondents. It was evident from the above results that the mean consumption of foods like cereals, pulses, sugar, fat and oils, and milk as well as roots and tubers was high on 0 day as compared to $90,120,150,180$, and the intake of fruits, vegetables, and other vegetables was very low on 0 day which drastically got increased on 90, 120, 150, 180 days due to increase in consumption of these food products. The study was in line with the study of Singh et al., (2010) where they studied the intervention for weight reduction among selected overweight obese women in an urban community of Varanasi studied overweight and obese women in the age group 20 to 49 years. Out of 619 eligible women screened in the community, 215 had BMI $\geq 25$ from 215 cases, 33 highly motivated women with an arbitrary cut off BMI of more than 28 were selected for an intervention programme to reduce their weight by enhancing their physical activities and modification in their dietary habits for three months after initiation of weight reduction programme, the average reduction in weight was $3.42 \pm 3.2 \mathrm{~kg}$ and it was statistically significant if compared to their baseline weight.

\section{References}

Binu, J. and Rajendra, H. (2014). A Study on the prevalence of overweight and obesity and its influencing factors among rural geriatric population in Kerala. International Journal of Current Microbiology and Applied Sciences 3(9):284-293.

National Family Health Survey 2015-16 (NFHS-2) states fact sheets rchiips.org/NFHS/factsheet_NFHS-

National Family Health Survey 2015-16 (NFHS-3) states fact sheets rchiips.org/NFHS/factsheet_NFHS-

Park and Park, (2002).Text Book of preventive and social medicine.M/S Banasidasbhanot publishers, Jabalpur.482001 (India)

Singh, V., Kaushik, A., Mishra, C. P., Mishra, S., and Singh, S. P.(2010).An intervention study for weight reduction among selected overweight / obese women in an urban community of Varanasi. Indian journal of social and preventive medicine 41(1).

World health Organization. 2000. Global data base on Body Mass Index. Retrieved from

http://apps.who.int/bmi/index.jsp?intro Page=intro_3.html.

World Health Organization. (2015). Preventing Chronic Diseases: a vital investment: $W H O$ global report. 
Geneva, Switzerland

World Health Organiztion (2015). Obesity:

Preventing and managing the global epidemic. WHO Technical Report
Series.894:113-114.National institute of health open assess6; 125(9): 11571170.

\section{How to cite this article:}

Sehar Siddiqui. 2021. Development of A Mobile Phone Application and its Efficacy Assessment Concerning the Changes in Anthropometric Measurements, and Dietary and Nutrient Adequacy of Hundred Obese Females of Udaipur City Rajasthan. Int.J.Curr.Microbiol.App.Sci. 10(10): 462-469. doi: https://doi.org/10.20546/ijcmas.2021.1010.056 